\title{
Ranking the importance of quality variables for the price of high quality beech timber (Fagus sylvatica L.)
}

\author{
Thomas KNOKE ${ }^{\text {a*}}$, Sebastian STANG ${ }^{\text {a }}$, Norbert REMLER ${ }^{\mathrm{b}}$, Thomas SEIFERT \\ ${ }^{a}$ Unit of Forest Inventory and Management, Technische Universität München, Germany \\ ${ }^{\mathrm{b}}$ Bavarian Forest Service, Germany \\ ${ }^{\mathrm{c}}$ Chair of Forest Yield Science, Technische Universität München, Germany
}

(Received 17 October 2005; accepted 15 November 2005)

\begin{abstract}
Based on the linear regression method this paper uses two econometric models to explain timber prices achieved for high quality beech timber (Fagus sylvatica L.). The modelling starts with the assumption that among other variables, the buyers' preference determines the level of the demand curve and therefore the price paid for specific goods of a given quantity. In a first step the buyers' preference was used as the central independent variable in an econometric model ("Price-preference-model"). The variable was derived through 4026 written buyers' bids for 980 high quality beech $\operatorname{logs}$ offered by the Bavarian State Forest Service in autumn 2001. The logs represented a total quantity of 2032 cubic meters $\left(\mathrm{m}^{3}\right)$. The number of bids for a specific timber log multiplied by its volume served as a proxy for the buyers' preferences, while indicating the potentially marketable amount of timber for a particular log. As a covariate the quantity of timber offered of a particular type, defined by timber diameter, length and quality grade was employed. Both variables, the buyers' preference and the timber quantity, accounted for $67 \%$ of the variation of the timber prices (RMSE \pm $\left.38.4 \mathrm{Euro} / \mathrm{m}^{3}\right)$. The buyers' preference absolutely dominated the model, alone accounting for $66 \%$ of the variation. The subsequently derived second econometric model ("Preference-quality-model") was utilised to explain the buyers' preference by means of relevant log size and quality variables. Among the set of independent quality variables, only the "red heartwood", the "stem curvature", the "spiral grain", the "growth stresses" and the "roughness of the bark" contributed significantly to explain the buyers" preference. The "Preference-quality-model" was able to explain 58\% of the variation of the actual buyers' preferences observed. Both models, the "Price-preference-model" and the "Preference-quality-model" were eventually combined in order to rank the timber quality variables according to their importance regarding the timber price. When combining both models an overall $r^{2}$ of 0.66 was achieved. Tests with independent data were successful. The ranking showed that the "red heartwood" is the most important timber quality variable, followed by "spiral grain", "stem curvature", "roughness of the bark" and "growth stresses". Moreover, an analysis of separate "Price-preference-models" and "Preference-quality-models" revealed clear differences between European and Asian buyers. While the Asian buyers were more interested in large logs (in terms of the diameter), the European buyers were more differentiated in their preferences with regard to the timber quality. If the "red heartwood" already covered 30\% of the stem's diameter, for example, it was not important for to Asian buyers, whether the red heartwood comprised of more or less than 50\%. "Growth stresses" and "Signs of old felling damage" played no quantifiable role in the "Preferencequality-model, Asia" while they did in the "Preference-quality-model, Europe". Where the "Roughness of the bark" was important for the Asian buyers, it was not relevant for the European market. Whereas the European buyers would prefer to buy stems with "red heartwood" comprising of less than $30 \%$ of the stem's diameter, the Asian buyers would accept a higher amount of "red heartwood".
\end{abstract}

timber price / timber quality / buyers' preference / econometric models / requirements of European and Asian buyers

Résumé - Classement de l'importance des variables qualitatives afin de fixer le prix du bois d'industrie du hêtre de haute qualité. Les auteurs utilisent deux modèles économétriques, basés sur la méthode de régression linéaire, afin d'expliciter le prix obtenu pour le bois d'industrie de hêtre de haute qualité (Fagus sylvatica L.). La modélisation s'appuie sur l'hypothèse que, parmi les variables, la préférence de l'acheteur détermine le niveau de la courbe de demande et ainsi le prix payé pour un bien spécifique d'une quantité donnée. Dans une première étape, la variable «préférence de l'acheteur» a été utilisé comme variable indépendante principale dans un modèle économétrique («modèle du prix préférentiel»). La variable a été estimée à partir de 4026 propositions d'achat pour 980 billons de hêtre de haute qualité offert, à l'automne 2001, par le service forestier de Bavière. Les billons représentaient un volume total de $2032 \mathrm{~m}^{3}$. Le nombre de proposition d'achat pour un billon spécifique, multiplié par son volume, a servi d'estimateur pour la variable "préférence de l'acheteur», tout en indiquant le potentiel commercial de la quantité de bois d'œuvre pour un billon spécifique. La quantité de bois d'œuvre proposé pour un certain type fut choisie comme covariate, elle est caractérisée par le diamètre de la grume, la longueur et la classe de qualité. Les deux variables, "préférence de l'acheteur » et «qualité de grume », expliquaient $67 \%$ de la variation des prix de grume $\left(\right.$ RMSE $\left.\pm 38,4 \mathrm{Euro} / \mathrm{m}^{3}\right)$. La variable «préférence de l'acheteur » dominait totalement le modèle, elle expliquait à elle seule $66 \%$ de la variation. Le second modèle économétrique développé postérieurement (modèle préférence-qualité) a été utilisé pour expliciter la variable «préférence de l'acheteur » au moyen de variables concernant la taille et qualité du billon. Parmi cet ensemble de variable qualitative indépendante, seul le « cœur rouge », la courbure de la tige, la texture spiralée, les stress de croissance et la rugosité de l'écorce ont contribué significativement à l'explication de la variable «préférence de l'acheteur ». Le modèle "préférence-qualité » a permis d'expliquer $58 \%$ de la variation de la variable observée "préférence de l'acheteur ». Les deux modèles ont éventuellement été combinés afin de classifier les variables de qualité de la grume en fonction de leur poids dans la détermination du prix de grume. Lorsque les deux modèles sont combinés, un $R^{2}$ de 0,66 est atteint. Les tests sur les valeurs indépendantes sont significatifs. La classification montrait que le cœur rouge est la variable la plus discriminante, suivie par la texture en spirale, la courbure du tronc, la rugosité de l'écorce. Cependant, une analyse séparée selon le modèle révèle des différences claires entre les acheteurs européens et asiatiques. Alors qu'en Asie, les acheteurs étaient plus intéressés par les grumes de grande taille (en termes de diamètre), les acheteurs Européens sont plus dispersés

\footnotetext{
*Corresponding author: knoke@ forst.tu-muenchen.de
} 
quant à leurs préférences par rapport à la qualité de la grume. Si, par exemple, le cour rouge atteint déjà $30 \%$ du diamètre du tronc cela est sans importance pour l'acheteur asiatique, jusqu'à ce qu'il atteigne ou dépasse $50 \%$. Les stress de croissance et les signes de dommage probable ne jouaient aucun rôle quantifiable dans le modèle "préférence-qualité » asiatique, tandis qu'ils étaient discriminants pour le modèle européen. Alors que la rugosité de l'écorce était une variable importante pour l'acheteur asiatique, elle ne l'était pas pour le marché européen. Les acheteurs européens préféreront l'acquisition de troncs avec moins ou jusqu'à $30 \%$ de cœur rouge, tandis que les acheteurs asiatiques accepteront une plus grande quantité de cœur rouge.

prix de grume / qualité de grume / préférence de l'acheteur / modèles économétriques / exigence des acheteurs européens ou asiatiques

\section{INTRODUCTION}

The profitability of forestry rises and falls with the timber price, because timber is virtually the only forest product sold on existing markets. It seems therefore important to analyse the relevant factors influencing the achievable timber price. Amongst other variables like regional variations of timber prices [5] and different information levels of the buyers [3] timber quality is the key factor to drive timber prices as it defines limits for timber utilisation. And it is a factor which can be objectively measured and described. Therefore, forest science tends to focus more intensively on timber quality analyses (e.g., $[2,17,23,39])$ and modelling (e.g., $[6,12,16,17,38$, 43]). In the past, several authors tried to rank the importance of specific timber quality variables [24, 36, 37]. Surprisingly econometric price analysis for timber logs, with timber quality measures as explanatory variables, is relatively scarce. In recent years, Alderman et al. [1] showed the importance of wood properties to distinguish between logs of different price categories. Göttlein [4] investigated the influence of timber quality variables on prices achieved for veneer oak in "Lower Frankonia" (Bavaria). But only a small part of the price dispersion could be explained in this study with the remaining estimation errors being great.

Particularly in the case of beech (Fagus sylvatica L.) there is a serious lack of information on the impact of timber qualities on the timber price and the marketable quantity. Such information was extremely important to improve the financial return of beech management, which from an economic point of view, was not very successful in the past [7]. Once the timber quality and through this the achievable timber price of beech become predictable, more realistic timber management concepts can be developed to optimise the return (e.g., [16]). For this purpose, price models are an essential link between timber quality and cash flows in order to model the consequences thoroughly of producing particular timber qualities.

In this context the paper presents such price models for high quality beech timber. A new modelling approach was used for ranking the importance of timber quality variables.

\section{THEORETICAL APPROACH, HYPOTHESES AND STRUCTURE OF THE STUDY}

Before estimating parameters of price models on an empirical basis, the structures of the models should be clarified. In order to improve the empirical relevance of the models derived, the choice of the dependent and independent variables as well as the way of their combination must be based on theoretical

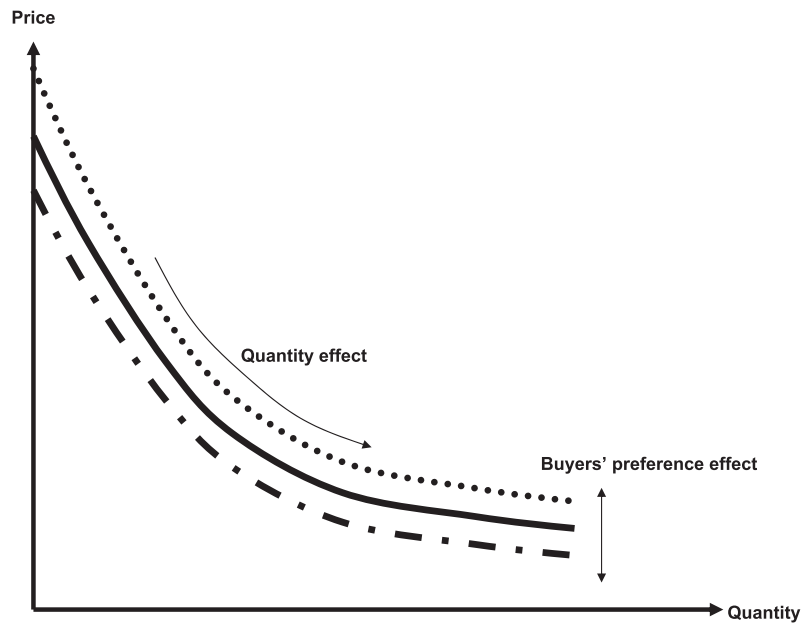

Figure 1. Quantity and quality effects on demand curves for homogeneous goods.

knowledge. It is well known that according to economic theory, the demand (i.e. the marketable quantities) of more or less homogenous goods (e.g., graded timber logs) is controlled by its price, if and only if, prices for substitute and other goods are known and if the income of the consumers and also the consumers' preference structure are given (e.g., $[4,20])$. Hence, the marketable quantities will decrease with increasing price and vice versa. It is therefore usual to assume down sloping demand curves for single enterprises as depicted in Figure 1 (see [42], p. 213). The negative slope of the demand curve seems logical because if the price is high, consumers will try to replace that product by others. Conversely, if the price is low, consumers will buy greater quantities of the cheap product to replace more expensive other products or simply to enhance their welfare by greater consumption.

Inversely, the slope of the demand curve reflects the fact that the price may be subject to quantity effects (see e.g., [22]). Therefore, an econometric price model should consider a quantity measure for the analysed goods as a covariate; although it may loose importance, if the offered quantities of the goods are small (see Discussion).

Quantity effects on the price will not aid in ranking the qualities of goods. The price variation along the demand curve is not subject to quality. Rather, the upward or downward movement of the demand curves as a whole, i.e. the change in the intercept of the curves as depicted in Figure 1, seems interesting in solving our problem. These movements may be directly explained by different preferences for various goods. This is not a contradiction of the described quantity effect. The latter 
describes price changes subject to the offered quantities on one specific demand curve for more or less homogenous goods. In contrast, the preference structure itself determines the level at which the demand curves slope downwards with an increasing quantity of goods. In theory, the price should increase with the growing preference for specific goods. The link to the qualities of the goods' is eventually formed by the fact that the consumer preferences themselves are often directly or indirectly controlled by the properties of the goods.

Solving the problem was therefore divided into two steps; the analysis of the buyers' preference and the incorporation of the qualities of the goods (i.e. timber logs). The first step was analysing the influence of the timber buyers' preferences for a specific logs, on the timber price achieved. Hence, a variable was generated as a proxy, in order to estimate the buyers' preference. The creation of this variable is described in a later section.

Based on the existing theory, the first econometric model ("Price-preference-model") was formulated accordingly with the following structure:

$$
\text { Price }_{i}=f\left(\text { Preference }_{i}, \text { Quantity }_{t}\right)
$$

where $i$ is the individual log and $t$ the log type.

Incorporating the qualities of the goods was carried out in a separate second step. A model to predict the preferences of the buyers' as the dependent, with the log size and quality variables being the independents was formed ("Preferencequality-model").

$$
\text { Preference }_{i}=f\left(\operatorname{Size}_{1, i}, \ldots, \text { Size }_{w, i}, \text { Quality }_{1, i}, \ldots, \text { Quality }_{z, i}\right) \text {. }
$$

The variables used to describe the timber quality represent a selection from a huge amount of descriptors for beech timber quality regarding the European round wood grading rules EN 1316-1 [8] and various publications covering the influence of branches, knobs, scars and stem curvature [36], spiral grain $[13,14,33]$, and internal growth stresses which can lead to severe cracks after felling $[9,21,28]$. Some other variables like T-cancer and roughness of the bark were additionally included, because they are known to have a certain influence on the buyers' preferences.

Based on these two models, the following hypothesis was tested to investigate the methodology proposed:

$\mathrm{H} 1$ : 'Integrating a proxy for the buyers' preference in a two-stage approach does not significantly improve the price prediction."

As Necesany pointed out as early as 1969 [26], the "red heartwood" is the most important factor in beech timber devaluation. It seemed interesting to test, whether this is still true. Advertising campaigns carried out since this time, in order to increase the demand for beech with red heartwood, could have changed the situation. E.g., Richter [34] reported on such campaigns. The importance of "red heartwood" was subject to investigation in the second hypothesis:

$\mathrm{H} 2$ : "Among the quality variables the "red heartwood" looses on relevance."
Moreover, we used the available data to fit both models (Eq. (1) and (2)) separately for European and Asian buyers in order to analyse possible differences. Hence, a third hypothesis was addressed:

H3: "The "Price-preference-model" and the "Preferencequality-model" is to be the same for European and Asian buyers."

In the following section, we describe the data employed in the creation of dependents and independents, as well as the statistical methods applied. The results on the effect of the buyers' preference on the timber prices, the influence of timber size and quality variables on the buyers' preference, the errors produced when computing both models successively, an attempt at ranking the importance of the quality variables and differences between European and Asian buyers are subsequently presented. The study concludes with a discussion in which we compare the results achieved with existing knowledge.

\section{DATA EMPLOYED AND STATISTICAL METHOD}

\subsection{Data of the timber auction}

Data was used from an auction of high quality beech timber (predominantly large $\operatorname{logs}$ ) conducted by the Bavarian State Forest Service in autumn 2001. The timber was publicly offered and then sold according to written price bids of the timber buyers. For every log to be sold a price minimum (reserve price) was required by the Forest Service. Basically the highest bid was successful. However, in some cases only the price minimum was achieved. Generally the timber buyers did not know the bids of other timber buyers. An amount of $980 \operatorname{logs}$ representing 2032 cubic meters $\left(\mathrm{m}^{3}\right)$ were analysed, only two $\operatorname{logs}$ remained unsold. For this timber quantity a total of 4026 written price bids were received by the Forest Service from a total of 27 buyers. The timber export to Asia greatly influenced the structure of the timber buyers. Hence, $50 \%$ of the bids resulted from timber-export-corporations, $18 \%$ from timber exporting and high quality veneer producing corporations, $16 \%$ of the bids were presented by the saw mill industry, whereas $10 \%$ originated from low quality veneer producers and $6 \%$ from high quality veneer corporations. Because of this fact, in addition to analyses for all buyers, separate models were computed for European and Asian buyers in order to consider potential differences.

Data on the price bids for each log, the log size variables (mid diameter, length) and also the quality grades of the logs estimated by the forest rangers (seven grades were used) were provided by the Forest Service.

In order to characterise the log quality several quality parameters were measured, which is described in later sections. 


\subsection{Description of dependent and independent variables}

\subsubsection{Price-preference-model}

\subsubsection{The timber price as a dependent (in Euro/ $\mathrm{m}^{3}$ )}

Following evidence of preliminary calculations the best results were obtained when using the highest bid as the dependent variable. Analysing the mean prices formed of all bids for one $\log$ resulted in unsatisfactory models. Consequently, the highest price, at which the log was actually sold, served as the dependent to be analysed. The average price achieved was 207 Euro/ $\mathrm{m}^{3}$ with a minimum of 0 and a maximum of 547 Euro/m $\mathrm{m}^{3}$.

\subsubsection{The independents}

Within the econometric "Price-preference-model" only two independent variables were considered.

\section{Buyers'preference}

The buyers' preference is supposed to be the crucial variable in our approach. It seems clear that a high frequency of bids for one log would indicate a great interest of the timber buyers. To describe the buyers' preference, the number of bids for one log was multiplied by its volume. This variable served as a proxy for the buyers' preference, thus indicating the potentially marketable amount of timber of a particular log. In other words, a variable was formed expressing the quantity of a specific log that could have been sold. As Figure 2 indicates the timber prices actually appear to be correlated to the buyers' preference, thus showing the proxy being effective.

On average every log received 4 price bids, whilst the most preferred logs received up to 15 price bids (with a range of the bidden prices for the most valuable logs between 133 and 547 Euro $/ \mathrm{m}^{3}$ ). The buyers' preferences (number of bids multiplied by log volume) formed a range of 0.90 to $46.56 \mathrm{~m}^{3} / \mathrm{log}$ (mean $8.87 \mathrm{~m}^{3} / \log$ ).

\section{Log type quantity}

The log type quantity of a specific log class offered was formed on the basis of the log classification carried out by local forest rangers. Timber volumes of logs of an identical size (i.e., equal mean diameter and length) and quality grade were computed. While combining mean diameter, length and quality grade a total of $402 \log$ types occurred. Log type quantity values lay between 0.60 and $21.07 \mathrm{~m}^{3} / \mathrm{log}$ type (mean $5.05 \mathrm{~m}^{3} / \log$ type).

\subsubsection{Preference-quality-model}

The "Preference-quality-model" contained the buyers' preference as the dependent variable, which in the "Pricepreference-model" served as an independent.

A great range of independent variables was measured comprising of log size and quality variables. The range is reported
Table I. Coding of non-metric independents.

\begin{tabular}{|c|c|c|c|c|}
\hline Log quality variable & $\mathrm{j}$ & $\mathrm{I} 1_{j}$ & $\mathrm{I} 2_{j}$ & $\mathrm{I} 3_{j}$ \\
\hline Red heartwood & 1 & & & \\
\hline Class 1: No red heartwood & & 1 & 1 & 0 \\
\hline Class 2: $>0$ up to $30 \%$ & & 1 & -1 & 0 \\
\hline Class 3: $>30$ up to $50 \%$ & & -1 & 0 & 1 \\
\hline Class $4:>50 \%$ & & -1 & 0 & -1 \\
\hline Signs of old felling damage & 2 & & & \\
\hline Class 1: No signs & & 2 & 0 & \\
\hline Class 2: On one side of log & & -1 & 1 & \\
\hline Class 3: On more than one side & & -1 & -1 & \\
\hline Stem curvature & 3 & & & \\
\hline Class 1: Up to $2 \mathrm{~cm} /$ meter & & 2 & 0 & \\
\hline Class 2: $>2 \mathrm{~cm}$ (curvature in one direction) & & -1 & 1 & \\
\hline Class 3: $>2 \mathrm{~cm}$ (curvature in two directions) & & -1 & -1 & \\
\hline Spiral grain & 4 & & & \\
\hline Class 1: Up to $6 \mathrm{~cm} /$ meter & & 2 & 0 & \\
\hline Class 2: $>6$ up to $15 \mathrm{~cm} /$ meter & & -1 & 1 & \\
\hline Class $3:>15 \mathrm{~cm} /$ meter & & -1 & -1 & \\
\hline Growth stresses & 5 & & & \\
\hline Class 1: Without & & 1 & & \\
\hline Class 2: With & & -1 & & \\
\hline Roughness of the bark & 6 & & & \\
\hline Class 1: Smooth & & 1 & & \\
\hline Class 2: Harsh & & -1 & & \\
\hline
\end{tabular}

for every variable, defining the validity field of the models derived.

The coding of non-metric variables recorded in classes is presented in Table I.

The log size variables

In order to integrate the log size, the mid diameter (diameter outside bark measured in $\mathrm{cm}$ at half of the length of the log) and the log length (in $\mathrm{m}$ ) were used. The mid diameters of the logs lay between 45.0 and $77.0 \mathrm{~cm}$ (mean $57.13 \mathrm{~cm}$ ) while the length had values from 3.2 up to $15.2 \mathrm{~m}$ (mean $8.01 \mathrm{~m}$ ).

\section{The red heartwood}

During the fieldwork it was recorded, whether or not „red heartwood" was visible at the felling cut of the log. When stems with even very small "red heartwood" were observed, they were also categorised as "red heartwood". Several types of "red heartwood" exist, which were described by Sachsse [35] and Seeling [37]. In this study, however, only the classical "red heartwood" occurred.

If present, the extent of the red heartwood was measured at its longest diameter in $\mathrm{mm}$. The red-heartwood-diameter was then compared with the diameter of the log and the quotient red-heartwood-diameter/stem diameter times 100 was 


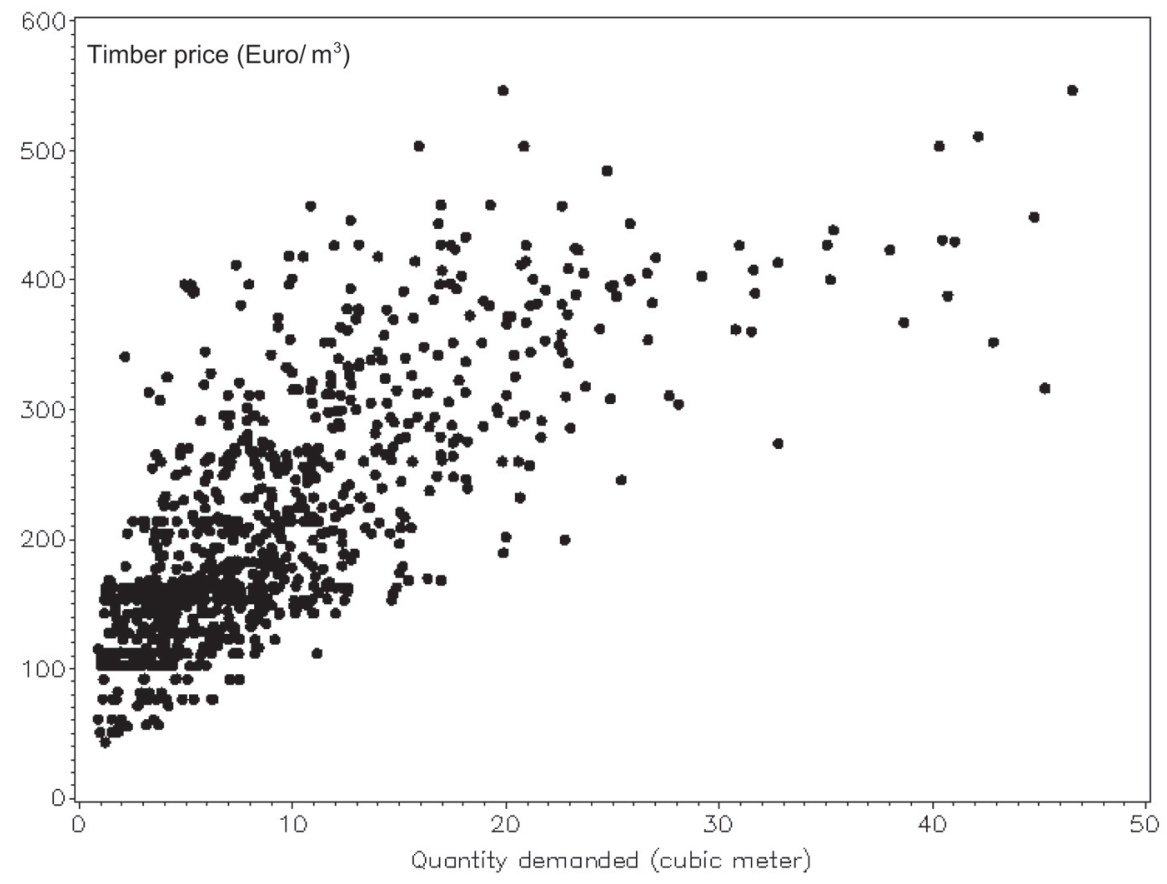

Figure 2. Relation between timber price (winning bid) and the buyers' preference.

formed. This quotient expressed the proportion of the redheartwood-diameter compared to the stem diameter in percent (red-heartwood-proportion).

In order to simplify red heartwood modelling in further studies (e.g., $[15,16])$ only the red heartwood at the felling cut was used as an indicator to reflect the influence of red heartwood on the timber price.

Only $144 \operatorname{logs}(15 \%)$ showed no red heartwood at the felling cut. The average heartwood diameter was $132 \mathrm{~mm}$ (550 $\mathrm{mm}$ was the maximum). The corresponding redheartwood-proportion was $18 \%$ (with a maximum of $91 \%$ ).

According to the red-heartwood-proportion, the logs were classified into four red-heartwood-types defined in Table I. The red heartwood was then integrated as a quality variable in the regression model by means of three indicator variables.

Signs of overgrown old branches

Scars on the bark, indicating the former presence of branches, were counted. Their number was then divided by the log length forming the number of scars per meter log length. On average 0.17 scars $/ \mathrm{m}$ were counted, while the extreme values were 0 and $2.58 \mathrm{scars} / \mathrm{m}$.

\section{Signs of old felling damage}

Every log was visually analysed regarding old felling damages at four log sides. The majority of logs, 655 of $980(67 \%)$ showed no felling damage, while 272 had felling damages on one side of the log, 49 on two sides and 4 on more than two sides.

Three classes were formed to express the intensity of old felling damages (Tab. I).
The knobs

Similar to the scars, knobs also indicate the former presence of a branch. They, however, are the more serious constraints for the timber quality, as they represent recently overgrown and quite large, already decomposed branches. The number of knobs was counted and analogous to the scars divided by the $\log$ length. The average frequency per meter was 0.02 with dispersion from 0 to $4.11 \mathrm{knobs} / \mathrm{m}$.

\section{The stem curvature}

The stem curvature expresses at which extent the longitudinal $\log$ axis deviated from a straight line. It was measured for the whole $\log$ in $\mathrm{cm}$ and then divided by the log length. If the stem curvature was less than $2 \mathrm{~cm} / \mathrm{m}$ it was not considered as a constraint of the log's quality. With more than $2 \mathrm{~cm} / \mathrm{m}$ the interference of timber quality depended on whether the curvature had only one or more directions. Three classes were used (Tab. I).

Overall 746 logs showed a stem curvature of less than $2 \mathrm{~cm} / \mathrm{m}, 218$ had a greater stem curvature but only in one direction and 16 had a curvature greater than $2 \mathrm{~cm} / \mathrm{m}$ in more than one direction.

\section{The spiral grain}

Spiral grain means a helical course of timber fibres around the stems' centre. It was measured in $\mathrm{cm}$ as the average deviation of the bark's fibres to a straight line parallel to the stem axis. The spiral grain was measured per meter and added up. Similar to other measures the total deviation was then divided by the log length, in order to obtain an average value. Again three classes were formed to characterise the spiral grain (Tab. I). 
More than $80 \%$ of the $\operatorname{logs}$ had a spiral grain of less than $6 \mathrm{~cm} / \mathrm{m}, 117$ showed a spiral grain of between 6 and $15 \mathrm{~cm} / \mathrm{m}$ and $57 \log$ s exhibited a serious spiral grain of greater than $15 \mathrm{~cm} / \mathrm{m}$.

The growth stresses

A crack from the logs centre to its outer border was seen as an indication of growth stresses within the stem. This log property was only classified as present (class 2 ) or not present (class 1). 360 logs showed signs of growth stresses within the stem.

The roughness of the bark

The bark was visually classified as smooth (class 1 ) or harsh (class 2). 190 logs showed a harsh bark.

Signs of "t-cancer" at the bark

Signs of "t-cancer" are circular scars resulting e.g. from the insect Cryptococcus fagisuga LIND. OR HAIL. They indicate a so called "t-cancer" inside the log. Signs of "t-cancer" were counted and divided by the log length. On average 1.27 signs/m were counted with a maximum of 13.49 signs $/ \mathrm{m}$.

\subsection{Statistical analysis}

\subsubsection{Regression analysis}

For the "Price-preference-model" Price $_{i}=f$ Preference $_{i}$, Quantity $\left.{ }_{t}\right)$ ) the following basic structure of a statistical regression curve was formulated:

$$
\text { price }_{i}=b_{0}+b_{1} \cdot \text { preference }_{i}+b_{2} \cdot \text { quantity }_{t} \pm \varepsilon .
$$

In the case of the "Preference-quality-model" (Preference ${ }_{i}=$ $f\left(\right.$ Size $_{1, i}, \ldots$, Size $_{w, i}$, Quality $_{1, i}, \ldots$, Quality $\left.\left._{z, i}\right)\right)$ a similar basic structure was applied:

$$
\begin{aligned}
\text { preference }_{i}= & b_{0}+b_{1} \cdot d_{i}+b_{2} \cdot l_{i}+b_{3} \cdot I 1_{1, i}+\ldots+b_{8} \cdot I 1_{6, i} \\
& +b_{9} \cdot I 2_{1, i}+\ldots+b_{12} \cdot I 2_{4, i}+b_{13} \cdot I 3_{1, i} \\
& +b_{14} \cdot \text { knobs }_{i}+b_{15} \cdot \text { scars }_{i}+b_{16} \cdot \text { tcancer }_{i} \pm \varepsilon
\end{aligned}
$$

\footnotetext{
price $_{i}: \quad$ The timber price per cubic meter $\left(\mathrm{Euro} / \mathrm{m}^{3}\right)$ of $\log \mathrm{i}$;

preference $_{i}$ : Volume $\left(\mathrm{m}^{3} / \mathrm{log}\right)$ which potentially could have been sold of the $\log i$

quantity $y_{t}$ Volume offered of log type $t\left(\mathrm{~m}^{3} / \log\right.$ type);

$d_{i}$ : $\quad$ Diameter in $\mathrm{cm}$ measured at half of the log length (outside bark) of $\log i$;

$l_{i}$ : $\quad$ Length in $\mathrm{m}$ of $\log \mathrm{i}$;

$I 1_{1, i} \ldots I 1_{6, i}$ : Indicators for non-metric quality variables of $\log i$ according to Table I;

$I 2_{1, i} \ldots I 2_{4, i}$ Indicators for non-metric quality variables of $\log i$ according to Table I;

$I 3_{1, i}$ : Indicator for non-metric quality variables of $\log \mathrm{i}$ according to Table I;

knobs $_{i}: \quad \quad$ Number of knobs per meter of $\log i(\mathrm{knobs} / \mathrm{m})$;

scars $_{i}: \quad \quad$ Number of scars per meter of $\log i(\mathrm{scars} / \mathrm{m})$;

tcancer $_{i}: \quad$ Number of signs of "t-cancer" per meter of $\log i($ signs $/ \mathrm{m})$;

$\varepsilon: \quad \quad$ Not explained dispersion (residuals)
}

To be able to test the advantage of the two-stage approach based on the buyers' preference, another model was analysed as a reference (Eq. (5)). This model estimated the timber prices directly on the basis of log size and quality variables, thus ignoring the additional information on the buyers' preferences.

$$
\begin{aligned}
\text { price }_{i}= & b_{0}+b_{1} \cdot d_{i}+b_{2} \cdot l_{i}+b_{3} \cdot I 1_{1, i}+\ldots+b_{8} \cdot I 1_{6, i} \\
& +b_{9} \cdot I 2_{1, i}+\ldots+b_{12} \cdot I 2_{4, i}+b_{13} \cdot I 3_{1, i} \\
& +b_{14} \cdot \text { knobs }_{i}+b_{15} \cdot \text { scar }_{i}+b_{16} \cdot \text { tcancer }_{i} \pm \varepsilon
\end{aligned}
$$

A fundamental assumption in linear regression analysis is that all residuals have the same variance. In the described models, however, an increase of variation for larger values of the response variables occurred. Hence a logarithmic transformation was carried out, which is widely used in such cases [10]. Moreover, following Quinn and Keough [29] the fourth root of metric independents was often used to normalise their distributions. These variables were provided with an exponent of 0.25 .

The procedure "proc reg" of the statistic program SAS (version 8) was used to estimate the parameters of the regression curves and the option "selection = stepwise" was enabled (significance level to enter the model 0.05 and significance level to stay 0.10 ). Observations with standardised residuals outside a range of \pm 2 were seen as outliers and eliminated.

\subsubsection{Testing the quality of the models}

The quality of the models was not only evaluated by means of the $r^{2}$ (measure of determination). Particularly the distribution of the residuals was evaluated to select the best model.

Before estimating the parameters of both models ("Pricepreference-model" and "Preference-quality-model"), 100 observations were randomly chosen and excluded from the data set in order to obtain independent data. These data were used as an independent data set to test the models.

To measure the overall explanatory power of both models when applied successively, the proportion of the explained sum of the squares (ESS) in relation to the total sum of squares (TSS) was formed and seen as an overall $r^{2}$. The ESS was based on differences between predicted price values by combining both models and the mean price. The differences were squared and eventually totalled. Computing the TSS comprised of the differences between the actual observed price values and the mean, which were squared and then totalled analogously.

\section{RESULTS}

In order to test the first hypothesis we started the analysis ${ }^{1}$ with a one-stage model excluding the buyers' preference. This model estimated the timber price directly on the basis of log

\footnotetext{
${ }^{1}$ Generally 880 observations were used for the parameter estimation (980 total observations minus 100 observations which were excluded in order to form the test independent data). The number of observations employed for the final versions of the models after the elimination of outliers is given with every respective Table.
} 
Table II. Regression results for a standard model excluding the buyers' preference ( $n$ after elimination of outliers: 821).

\begin{tabular}{|c|c|c|c|c|c|c|c|}
\hline Dependent & Independent & & Order of affiliation & Parameter & Standard-error of parameter & $p$-value & $r^{2} \operatorname{RMSE}\left(\mathrm{m}^{3} / \log \right)$ \\
\hline \multirow[t]{9}{*}{$\ln \left(\right.$ price $\left._{i}\right)$} & Intercept & & & $b_{0}: 3.21967$ & 0.13872 & $<0.0001$ & 0.29 \\
\hline & Diameter & $d_{i}^{0.25}$ & 1 & $b_{1}: 0.02454$ & 0.00226 & $<0.0001$ & $\pm \quad 57.8$ \\
\hline & Length & $l_{i}^{0.25}$ & 4 & $\mathrm{~b}_{2}: 0.04188$ & 0.00555 & $<0.0001$ & \\
\hline & Red heartwood & $I 1_{1, i}$ & 3 & $\mathrm{~b}_{3}: 0.21306$ & 0.02619 & $<0.0001$ & \\
\hline & & $I 2_{1, i}$ & 8 & $b_{9}: 0.04346$ & 0.01753 & 0.01330 & \\
\hline & & $I 3_{1, i}$ & 7 & $b_{13}: 0.15713$ & 0.04904 & 0.00140 & \\
\hline & Spiral grain & $I 1_{4, i}$ & 5 & $\mathrm{~b}_{6}: 0.04900$ & 0.00979 & $<0.0001$ & \\
\hline & Stem curvature & $I 1_{3, i}$ & 6 & $b_{5}: 0.03571$ & 0.00856 & $<0.0001$ & \\
\hline & Roughness of bark & $I 1_{6, i}$ & 2 & $\mathrm{~b}_{8}: 0.11273$ & 0.01541 & $<0.0001$ & \\
\hline
\end{tabular}

Table III. Regression results for the "Price-preference-model" (parameters for data without logs sold at the minimum required price in parentheses, $n$ after elimination of outliers: 813).

\begin{tabular}{lcccccc}
\hline Dependent & Independent & Order of affiliation & Parameter & Standard-error of parameter & $p$-value & $r^{2}$ RMSE $\left(\right.$ Euro $\left./ \mathrm{m}^{3}\right)$ \\
\hline $\ln \left(\right.$ price $\left._{i}\right)$ & Intercept & & $\mathrm{b}_{0}: 3.48213(3.42219)$ & 0.04595 & $<0.0001$ & 0.67 \\
& preference $_{i}^{0.25}$ & 1 & $\mathrm{~b}_{1}: 1.06228(1.11052)$ & 0.03018 & $<0.0001$ & \pm 38.40 \\
& quantity $_{i}^{-2.4}$ & 2 & $\mathrm{~b}_{2}: 0.11966(0.12330)$ & 0.02679 & $<0.0001$ & \\
\hline
\end{tabular}

size and quality variables as independents (Tab. II). It achieved a $r^{2}$ of merely 0.29 . The root mean square error (RMSE) of the model remained comparatively high, obtaining a value of $\pm 57.8 \mathrm{Euro} / \mathrm{m}^{3}$.

\subsection{Estimating the effect of the buyers' preference on price}

Accordant to our expectation the prices observed showed a close correlation to the buyers' preference. Sixty six percent of the price dispersion could be explained by means of the buyers' preference alone. In contrast to the demonstration in the schematic Figure 1 the quantity offered of a specific log type, though highly significant, explained only $1 \%$ of the price dispersion (see discussion for potential reasons). Hence, the buyers' preference proved to be a highly relevant independent variable. The metric results of the regression analysis are presented in Table III.

As Figure 3 shows the residuals of the "Price-preferencemodel" were distributed more or less homogeneous above the predicted values. A systematic pattern is albeit partly visible in the scatter plot of residuals. The systematic pattern can be found due to the fact that some logs were sold for the minimum timber price per $\mathrm{m}^{3}$ (reserve price). As mentioned earlier, the minimum price was demanded by the forest service as a starting price. The logs were not sold for lower prices (this was the case only for two logs). Despite the systematic pattern of the residuals we emphasise that all $\log$ s were auctioned and we are sure that no requirements of the regression analysis were violated through this. Removing the data of the logs sold for a minimum price, produced only slightly different parameters (see Tab. III). However, we did not follow the model without the minimum-price-logs, since it focuses only on one part of the population of auctioned $\log s$ with a mean of the timber price greater than achieved in reality.

Tests based on the independent data set resulted in an underestimation of timber prices of on average $8.81 \mathrm{Euro} / \mathrm{m}^{3}$. In relation to the mean observed price of the test data $(217.58$ Euro $/ \mathrm{m}^{3}$ ) the bias amounted to only $-4 \%$. Compared to the RMSE of the model $\left( \pm 38.40\right.$ Euro $/ \mathrm{m}^{3}$, see Tab. III $)$ the RMSE of the estimations for the independent data was greater. It showed a value of $\pm 48.68 \mathrm{Euro} / \mathrm{m}^{3}$.

\subsection{Estimating the effect of timber quality variables}

Being aware of the great importance of the buyers' preference for the timber prices it was essential to explain the buyers' preference as good as possible. Among the 17 independent size and quality variables tested, 10 showed a significant influence on the buyers' preference (Tab. IV).

The "Preference-quality-model" was able to explain 58\% of the observed buyers' preference dispersion. However, already $42 \%$ of the buyer preference dispersion was explained by the $\log$ size variables length (35\%) and mean diameter (7\%). The significant timber quality variables together explained $16 \%$ of the dispersion of the observed buyers' preferences. Despite the rather small proportion of dispersion explained by the timber quality variables, the model is consistent. All parameters have the expected signs and the variables integrated were predominantly highly significant. 


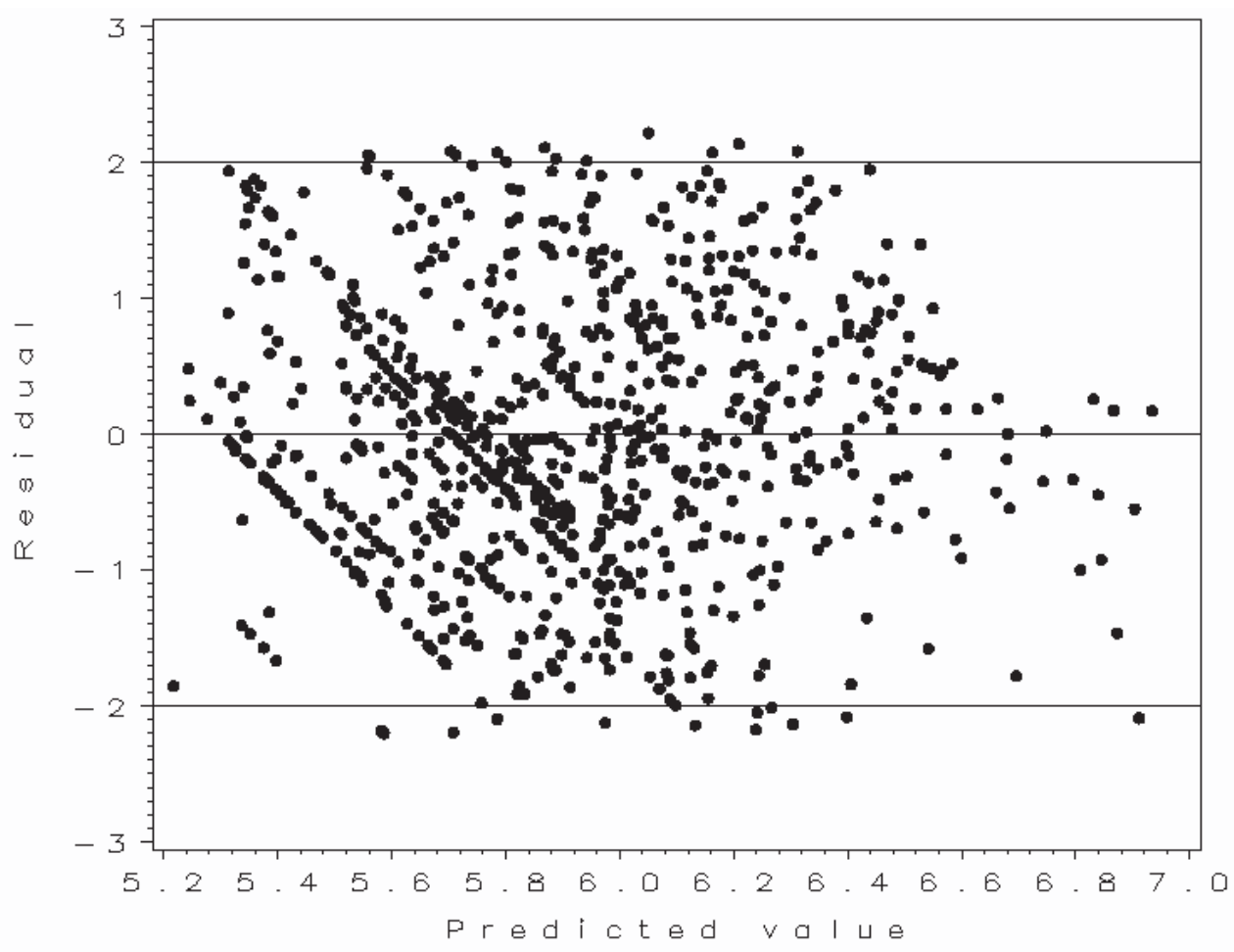

Figure 3. Standardised residuals for the "Price-preference-model" (unit of predicted variable $\ln ($ price)).

Table IV. Regression results for the "Preference-quality-model" (parameters for data without logs sold at the minimum required price in parentheses, $n$ after elimination of outliers: 831).

\begin{tabular}{|c|c|c|c|c|c|c|c|}
\hline \multirow{2}{*}{$\frac{\text { Dependent }}{\ln \left(\text { preference }_{i}\right)}$} & \multicolumn{2}{|l|}{ Independent } & \multirow[t]{2}{*}{ Order of affiliation } & Parameter & Standard-error of parameter & \multicolumn{2}{|c|}{$p$-value $r^{2} \operatorname{RMSE}\left(\mathrm{m}^{3} / \log \right)$} \\
\hline & Intercept & & & $b_{0}:-15.33978(-15.97673)$ & 0.76263 & $<0.0001$ & 0.58 \\
\hline & Diameter & $d_{i}^{0.25}$ & 2 & $b_{1}: 3.73929 \quad(4.15094)$ & 0.26733 & $<0.0001$ & $\pm \quad 3.38$ \\
\hline & Length & $l_{i}^{0.25}$ & 1 & $\mathrm{~b}_{2}: 3.90126 \quad(3.66306)$ & 0.15027 & $<0.0001$ & \\
\hline & Red heartwood & $I 1_{1, i}$ & 3 & $b_{3}: 0.30188 \quad(0.35484)$ & 0.03669 & $<0.0001$ & \\
\hline & & $I 2_{1, i}$ & 8 & $b_{9}: 0.08356 \quad(0.09173)$ & 0.02501 & 0.0009 & \\
\hline & & $I 3_{1, i}$ & 9 & $b_{13}: 0.14941 \quad(0.21461)$ & 0.06880 & 0.0302 & \\
\hline & Spiral grain & $I 1_{4, i}$ & 5 & $b_{6}: 0.11279 \quad(0.10715)$ & 0.01490 & $<0.0001$ & \\
\hline & & $I 2_{4, i}$ & 10 & $b_{12}: 0.08483 \quad(0.17115)$ & 0.04027 & 0.0355 & \\
\hline & Stem curvature & $I 1_{3, i}$ & 4 & $b_{5}: 0.10543 \quad(0.09609)$ & 0.01244 & $<0.0001$ & \\
\hline & Growth stresses & $I 1_{5, i}$ & 7 & $b_{7}: 0.06704 \quad(0.08320)$ & 0.01740 & $<0.0001$ & \\
\hline & Roughness of bark & $I 1_{6, i}$ & 6 & $b_{8}: 0.11344 \quad(0.14933)$ & 0.02204 & $<0.0001$ & \\
\hline
\end{tabular}

Analogous to the "Price-preference-model" the residuals for the "Preference-quality-model" were homogenously distributed and showed no trends (Fig. 4).

Calculations based on the test data set revealed a slight underestimation of the observed buyers' preference by $0.30 \mathrm{~m}^{3} / \log$, which amounts to a bias of $-3 \%$ (the mean buyers' preference for the test data was $8.61 \mathrm{~m}^{3} / \log$ ). When compared with the RMSE of the "Preference-quality-model" $\left( \pm 3.38 \mathrm{~m}^{3} / \mathrm{log}\right)$ the RMSE for the test data was hardly greater. It had a value of $\pm 3.63 \mathrm{~m}^{3} / \mathrm{log}$. Hence, the model estimates were quite robust.

\subsection{Applying both models successively and test of quality}

When combining the "Preference-quality-model" and the "Price-preference-model" (i.e. computing both models successively) to estimate timber prices, the explained sum of squares amounted to $66 \%$ of the total sum of squares (Tab. V). The relatively great explanatory power was achieved when the models were applied to the main data set used to estimate the parameters of the regression curves. However, even within the independent test data set, $52 \%$ of the variation of timber prices could be explained by the models. 


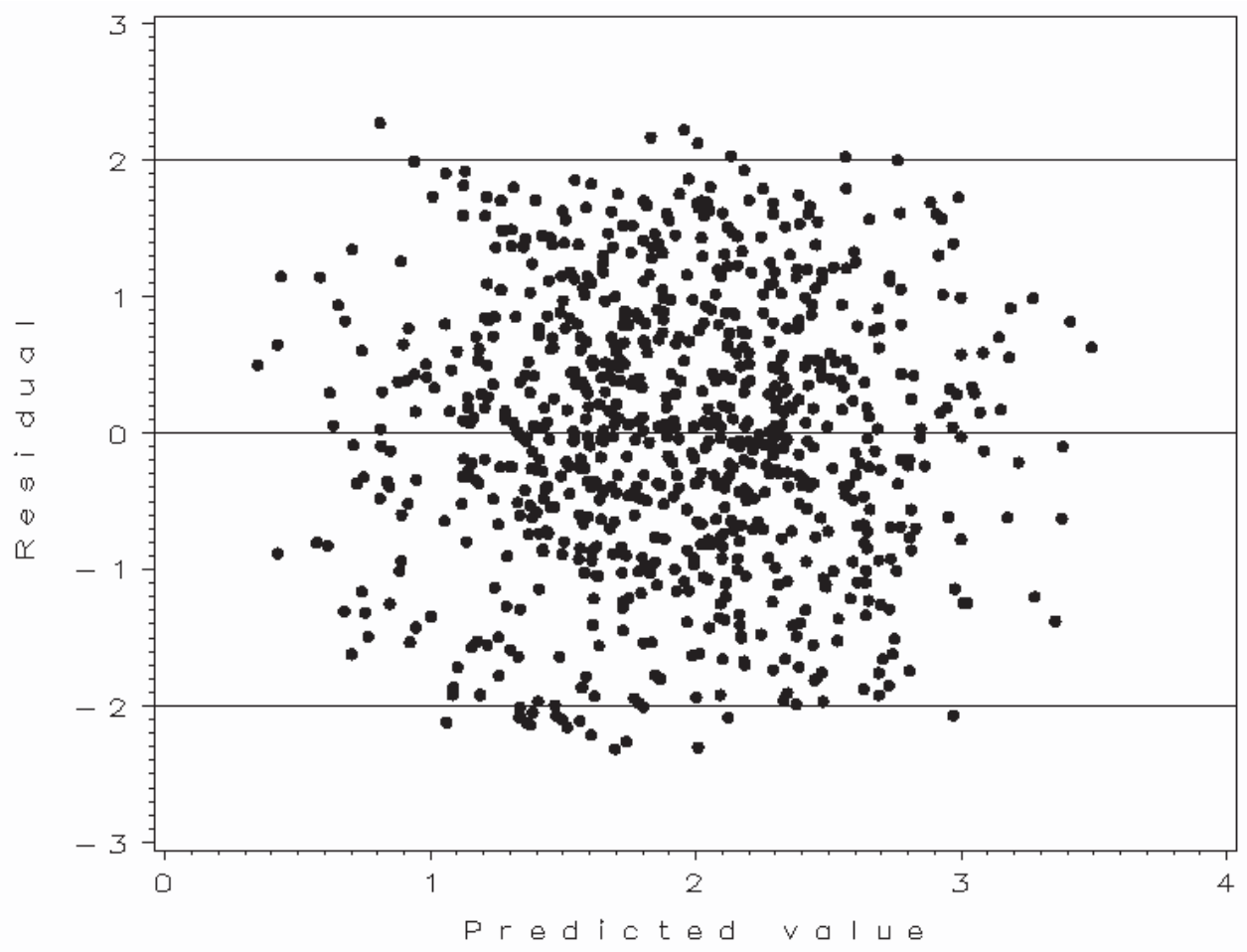

Figure 4. Standardised residuals for the "Preference-quality-model" (unit of predicted variable $\ln ($ preference)).

Table V. Data variation explained, root mean square errors and bias resulting of price predictions by the combination of the "Pricepreference-model" with the "Preference-quality-model".

\begin{tabular}{lcc}
\hline & $\begin{array}{c}\text { Main data set used for } \\
\text { parameter estimates } \\
(n=830)\end{array}$ & $\begin{array}{c}\text { Independent } \\
\text { test data } \\
(n=100)\end{array}$ \\
\hline $\begin{array}{l}\text { Explained Sum of } \\
\text { Squares (ESS) }\end{array}$ & 513081 \\
Total Sum of & 6353192 & 980969 \\
Squares (TSS) & & \\
Total $r^{2}$ & 0.66 & 0.52 \\
RMSE (Euro $\left./ \mathrm{m}^{3}\right)$ & \pm 38.6 & \pm 49.2 \\
Mean price $\left(\right.$ Euro $\left./ \mathrm{m}^{3}\right)$ & 205.24 & 217.58 \\
Bias $\left(\right.$ Euro $\left./ \mathrm{m}^{3}\right)$ & $-7.86(-4 \%)$ & $-11.19(-5 \%)$ \\
\hline
\end{tabular}

The total RMSE $( \pm 38.6)$ in the main data set was similar when compared with the "Price-preference-model" $( \pm 38.4)$. Predictions based on the test data were not that precise showing a RMSE of \pm 49.2 . The bias, however, is quite small (between -4 and $-5 \%$ ) regardless of the prediction for the main or for the independent test data set (Tab. V).

When compared to the performance of the model without the buyers' preference (one-stage approach) the results of the two-stage approach are clearly superior.

\subsection{Ranking the importance of timber quality variables}

The tests carried out for evaluating the models qualities proved a comparatively high explanatory power of each model as well as of the model combination and robust estimations even if an independent data set was used for the evaluation. Thus, it is likely that real effects were represented with the models rather than artefacts. A ranking of the importance of the timber quality variables on the basis of both models therefore seemed acceptable.

Among the quality variables the red heartwood describing variable $I 1_{1, i}$ was included as first. Its parameter has by far the greatest value. As seen in Figure 5 the timber price was reduced by about 52 Euro $/ \mathrm{m}^{3}$ when a $\log$ with no red heartwood was compared with one of more than $30 \%$ red heartwood proportion. But even if only a small red heartwood was present the price decreased by approximately $20 \mathrm{Euro} / \mathrm{m}^{3}$ (variable $\left.I 2_{1, i}\right)$. For the case that more than $50 \%$ of the logs' diameter contained red heartwood, the timber price sank by another 22 Euro $/ \mathrm{m}^{3}$ (variable $I 3_{1, i}$ ). Hence, the difference between a $\log$ without and one with more than $50 \%$ red heartwood amounted to 74 Euro $/ \mathrm{m}^{3}$ (36\% in relation to the average timber price achieved).

The importance of red heartwood becomes clearer when looking at the average price difference between a $55 \mathrm{~cm}$ and a $45 \mathrm{~cm}$ large $\mathrm{log}$, which is about $41 \mathrm{Euro} / \mathrm{m}^{3}$ (Fig. 6). Allowing a stem to grow from $45 \mathrm{~cm}$ to $55 \mathrm{~cm}$ will take 20 years, if the stem's diameter increment amounts to $0.5 \mathrm{~cm} /$ year. The 


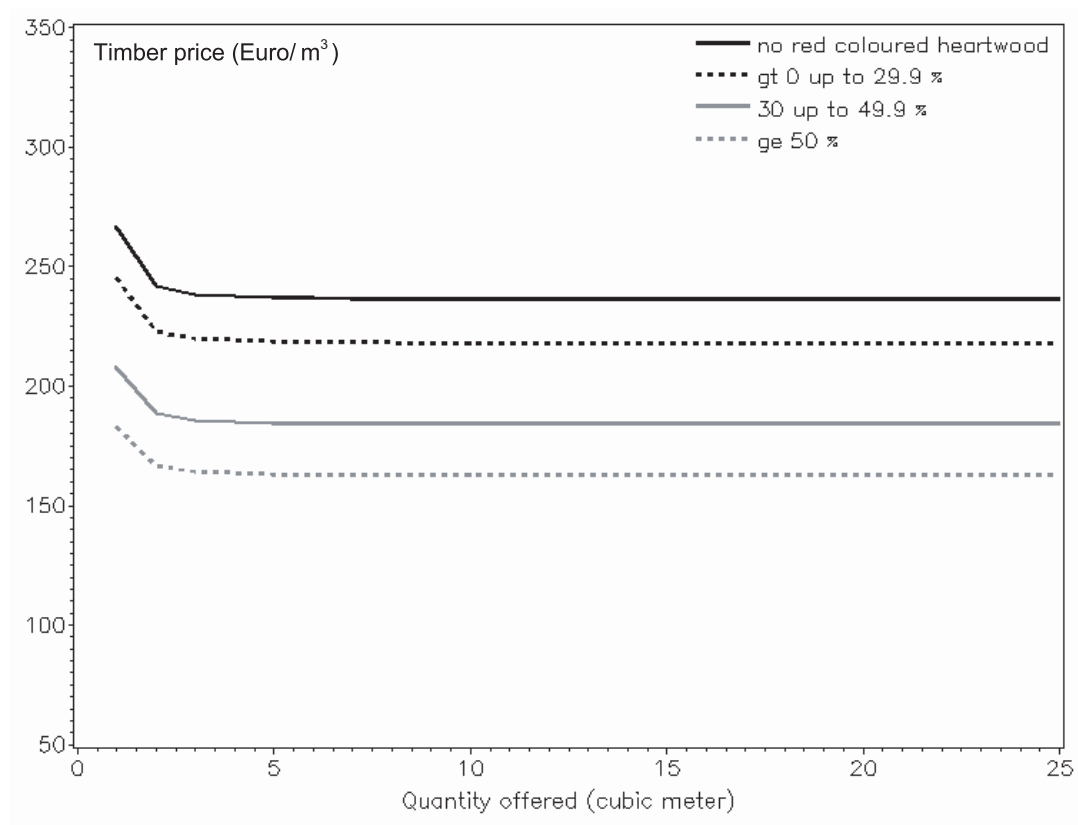

Figure 5. Influence of "red heartwood" on the timber price.

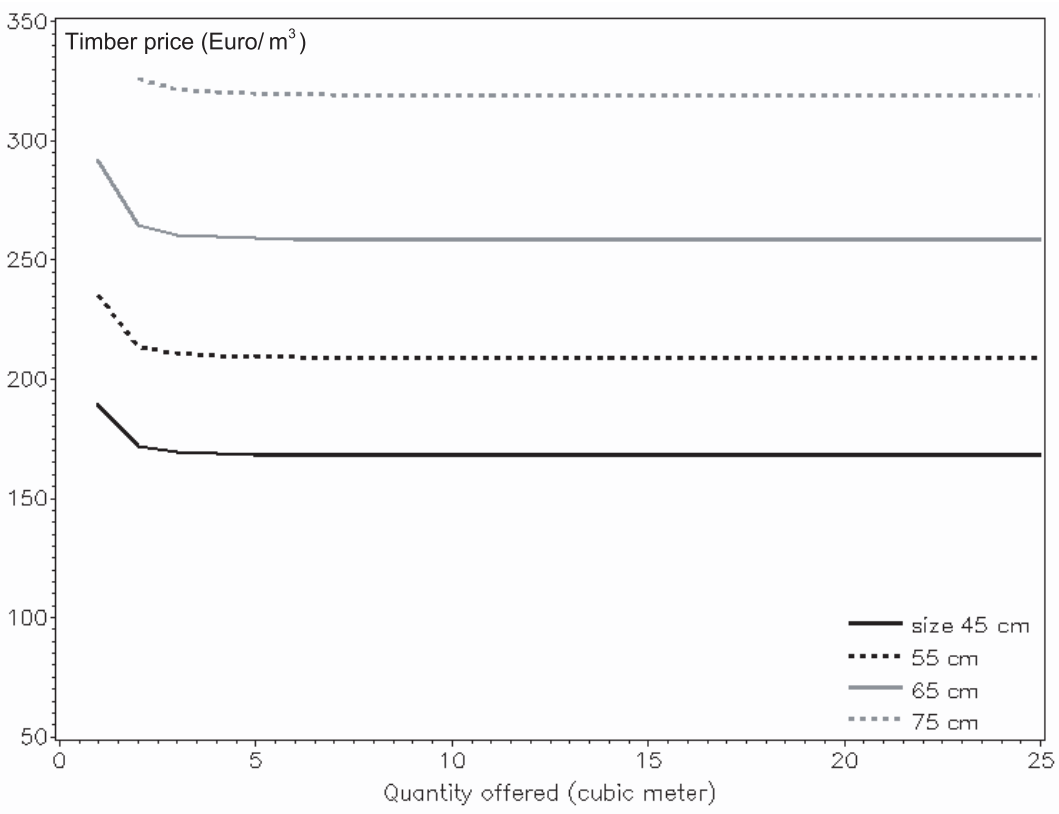

Figure 6. Influence of log size on the timber price.

increase in value connected with this diameter increment may be compensated by $3 / 4$ th if the red heartwood exceeds $30 \%$ of the log diameter during the 20 -year-period. The price is reduced by 32 Euro $/ \mathrm{m}^{3}$ in this case.

The most important timber quality variable after the red heartwood was the "spiral grain", which caused up to 43 Euro $/ \mathrm{m}^{3}$ price difference. The "spiral grain" was followed by "stem curvature", "roughness of the bark" and "growth stresses" (Tab. VI).

\subsection{Differences between European and Asian buyers}

As mentioned earlier Asian buyers made up 50\% of the bids. Because of this it could be analysed whether the "Pricepreference-model" and the "Preference-quality-model" differ for European and Asian buyers. Such analysis can reveal different evaluation of valuable beech timber logs by different types of buyers.

In a first step the "Price-preference-model" was supplemented with an indicator variable "buyer", which 
Table VI. Price reduction caused by different timber qualities.

\begin{tabular}{|c|c|c|c|}
\hline Log quality variable & $\begin{array}{l}\text { In Euro } / \mathrm{m}^{3} \text { compared } \\
\text { to a stem without quality constraints }\end{array}$ & $\begin{array}{c}\text { In } \% \text { related to the average } \\
\text { timber price }\left(205.24 \text { Euro/m } \mathrm{m}^{3}\right)\end{array}$ & Rank \\
\hline Red heartwood & & & 1 \\
\hline Class 2: $>0$ up to $30 \%$ & -20 & $-10 \%$ & \\
\hline Class 3: $>30$ up to $50 \%$ & -52 & $-25 \%$ & \\
\hline Class $4:>50 \%$ & -74 & $-36 \%$ & \\
\hline Spiral grain & & & 2 \\
\hline Class 2: $>6$ up to $15 \mathrm{~cm} /$ meter & -27 & $-13 \%$ & \\
\hline Class 3: $>15 \mathrm{~cm} /$ meter & -43 & $-21 \%$ & \\
\hline Stem curvature & & & 3 \\
\hline Class 2: $>2 \mathrm{~cm}$ (curvature one direction) & -33 & $-16 \%$ & \\
\hline Roughness of the bark & & & 4 \\
\hline Class 2: Harsh & -25 & $-12 \%$ & \\
\hline Growth stresses & & & 5 \\
\hline Class 2: With & -15 & $-7 \%$ & \\
\hline
\end{tabular}

Table VII. "Price-preference-model” for European and Asian buyers ( $n$ after elimination of outliers: 853).

\begin{tabular}{|c|c|c|c|c|c|c|}
\hline Dependent & Independent & Order of affiliation & Parameter & Standard-error of parameter & $p$-value & $r^{2}$ \\
\hline \multirow[t]{3}{*}{$\ln \left(\right.$ price $\left._{i}\right)$} & Intercept & & $\mathrm{b}_{0}: 3.52421$ & 0.05357 & $<0.0001$ & 0.56 \\
\hline & preference $_{i}^{0.25}$ & 1 & $\mathrm{~b}_{1}: 1.18206$ & 0.03637 & $<0.0001$ & \\
\hline & buyer ${ }^{1}$ & 2 & $b_{2}: 0.05504$ & 0.00951 & $<0.0001$ & \\
\hline
\end{tabular}

${ }^{1}$ Indicator variable, +1: Asian, -1 : European buyer.

distinguished between European (buyer $=-1$ ) and Asian buyers (buyer $=+1)$. For every category only the bids of European or only the bids of the Asian buyers were used to form the preference variable. Which bids either European or Asian to be considered depended on who actually bought the log (the buyer, European or Asian, bidding the highest price).

While the $r^{2}$ decreased by about 10 percent points in the model distinguishing the buyer group (compared to the original model), the variable "buyer" was significant (Tab. VII). The variable "quantity" was, however, excluded from this model, since it lost significance.

When inserting an average preference of $8.87 \mathrm{~m}^{3} / \log$ an expected price difference between Asian and European buyers of +28.74 Euro $/ \mathrm{m}^{3}$ resulted. This does not mean that the Asian buyers generally paid about $29 \mathrm{Euro} / \mathrm{m}^{3}$ more than the Europeans. The different preferences of the European and Asian buyers moderate the price differences. Thus, it was essential to fit separate regression curves for the "Preference-qualitymodel".

Again the $r^{2}$ of both models decreased compared to the overall model. For the "Price-preference-model, Europe" it was 17 percent points lower compared to the original model and for the "Price-preference-model, Asia" it dropped by $8 \%$ points. The "Price-preference-model, Europe" included $10 \mathrm{log}$ size and quality variables while the "Price-preference-model, Asia" contained only 7 (Tab. VIII).

Moreover, the order of affiliation of the variables was different between the models. While the "Price-preference-model, Asia" included the variable "diameter" already in the second step, the "Price-preference-model, Europe" included one of the "red heartwood" variables instead. The parameter of the diameter, which is much greater in the "Price-preferencemodel, Asia", indicates the great importance of the log dimension for the Asian buyers. Overall, the quality variables reflect a less pronounced preference differentiation in the "Price-preference-model, Asia" when compared to the "Pricepreference-model, Europe". For example, if the "red heartwood" already covered $30 \%$ of the stem's diameter, it was not important for the Asian buyers, whether it comprised of more or less than 50\%. "Growth stresses" and "Signs of old felling damage" played no quantifiable role in the "Price-preferencemodel, Asia", while they did in the "Price-preference-model, Europe". However, the "Roughness of the bark" was important for the Asian buyers whereas it was not so for the European buyers.

The differences regarding the expected timber price between the "Price-preference-models" for European and Asian buyers are exemplarily demonstrated in Figure 7. 
Table VIII. Separate "Preference-quality-models" for European and Asian buyers.

\begin{tabular}{|c|c|c|c|c|c|c|c|c|}
\hline \multirow[t]{2}{*}{ Dependent } & \multicolumn{2}{|l|}{ Independent } & \multicolumn{2}{|c|}{ Order of affiliation } & \multicolumn{2}{|c|}{ Parameter } & \multicolumn{2}{|c|}{$r^{2}$} \\
\hline & & & $\mathrm{E}$ & $\mathrm{A}$ & $E$ & $\mathrm{~A}$ & $E$ & $\mathrm{~A}$ \\
\hline \multirow[t]{12}{*}{$\ln \left(\right.$ preference $\left._{i}\right)$} & Intercept & & & & $\mathrm{b}_{0}:-15.33978$ & $\mathrm{~b}_{0}:-15.33978$ & 0.43 & 0.50 \\
\hline & Diameter & $d_{i}^{0.25}$ & 3 & 2 & $b_{1}: 2.30911$ & $b_{1}: 4.43169$ & & \\
\hline & Length & $l_{i}^{0.25}$ & 1 & 1 & $\mathrm{~b}_{2}: 3.27333$ & $\mathrm{~b}_{2}: 3.00914$ & & \\
\hline & Red heartwood & $I 1_{1, i}$ & 2 & 4 & $b_{3}: 0.33271$ & $b_{3}: 0.14844$ & & \\
\hline & & $I 2_{1, i}$ & 8 & 7 & $b_{9}: 0.09595$ & $b_{9}: 0.08599$ & & \\
\hline & & $I 3_{1, i}$ & 10 & - & $b_{13}: 0.18538$ & - & & \\
\hline & Signs of old felling damage & $I 1_{2, i}$ & 7 & - & $b_{4}: 0.07106$ & - & & \\
\hline & & $I 2_{6, i}$ & 9 & - & $b_{10}: 0.11093$ & - & & \\
\hline & Spiral grain & $I 1_{4, i}$ & 5 & 5 & $b_{6}: 0.07366$ & $b_{6}: 0.06193$ & & \\
\hline & Stem curvature & $I 1_{3, i}$ & 4 & 3 & $b_{5}: 0.08243$ & $b_{5}: 0.06979$ & & \\
\hline & Growth stresses & $I 1_{5, i}$ & 6 & - & $b_{7}: 0.08097$ & - & & \\
\hline & Roughness of bark & $I 1_{6, i}$ & - & 6 & - & $b_{8}: 0.08264$ & & \\
\hline
\end{tabular}

E: European buyers, A: Asian buyers, all variables had a $p$-value of less than 0.05 .

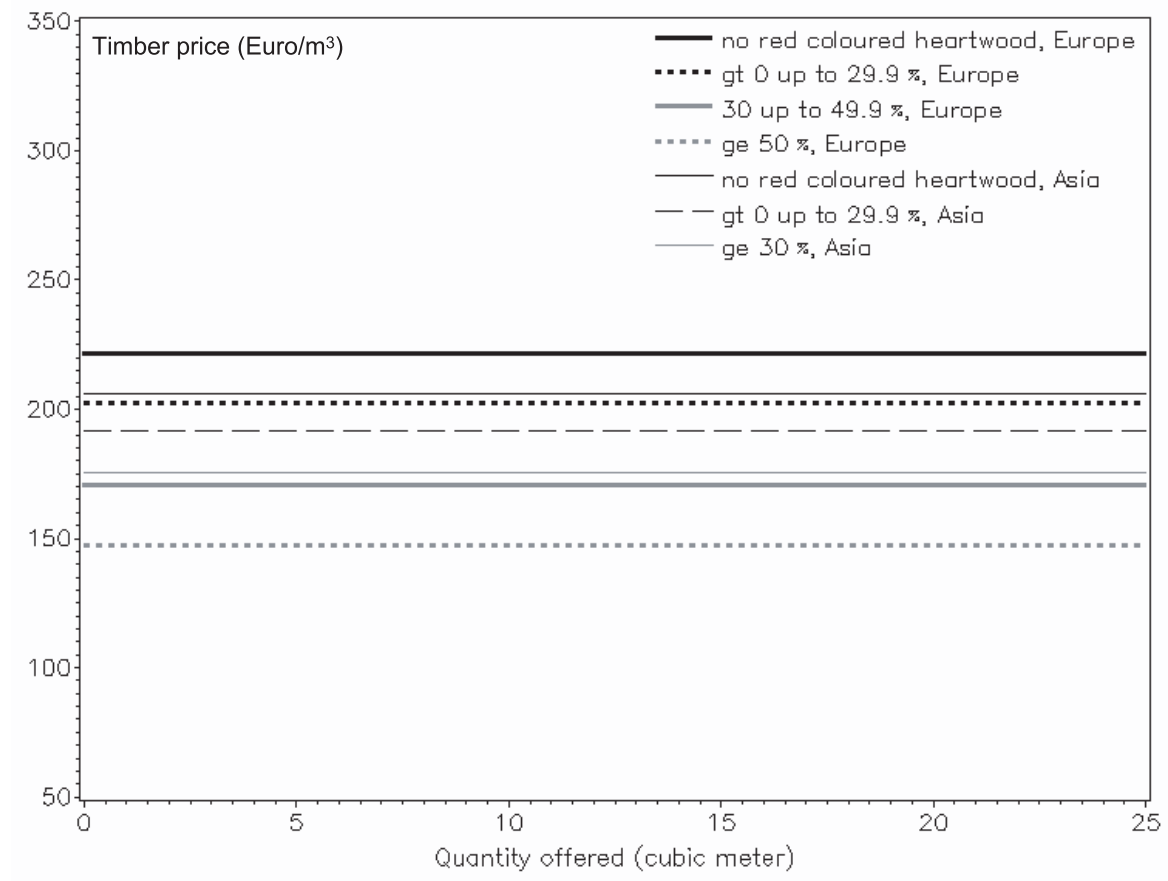

Figure 7. Comparison of expected prices from European and Asian buyers when different "red heartwood" qualities are offered.

It is obvious that the European buyers differentiate their prices more regarding the "red heartwood" quality. They would pay more for stems without or with only small "red heartwood" as compared to the Asian buyers. For example, the Asian buyers pay not more than almost the price for stems without "red heartwood" as the European buyers would spend for stems with "red heartwood" up to $29.9 \%$ of the stem's diameter. Consequently, stems with less than 30\% "red heartwood" would rather be bought by European buyers, while stems with more than $29.9 \%$ of "red heartwood" would be purchased by Asian buyers.

\section{DISCUSSION AND CONCLUSIONS}

\subsection{Answers to the hypotheses}

The objective of our paper was to find an answer to specific hypotheses. The first hypothesis tested was:

H1: "Integrating a proxy for the buyer preference in a two-stage approach does not significantly improve the price prediction."

The conduction of a two-stage approach based on the buyers' preferences was clearly superior to the one-stage approach 
ignoring the buyers' preference; hence, hypotheses H1 may be rejected.

With the buyers' preference valuable information could be used within the two-stage approach. This information is lost in a one-stage approach, when direct estimations of the timber prices are conducted. Moreover, the errors of both models in the two-stage approach (price-preference and preferencequality-models) did not seem to be positively correlated. The overall $r^{2}$ was almost as high as that of the price-preferencemodel, which showed the greatest $r^{2}$ of both single models. Obviously a compensation of estimation errors occurred in some cases. Given an underestimation of the preferencequality-model in several cases the price-preference-model must have overestimated and vice-versa.

Other studies on timber price modelling are scarce. Reddy and Bush [31] used a conjoint analysis approach to determine softwood lumber value perceptions among buyers of wood. The approach considered the timber price as an independent variable affecting the value timber buyers allocate to specific timber logs. In our study, however, the consumer price (not value) was the dependent variable to be predicted. Consequently, the study of Reddy and Bush [31] cannot be used for comparison. Looking at the problem under consideration from a statistical point of view, it seems that former studies did not reveal models as good as in this study. In the diploma thesis of Stang [40] the best price model showed a $r^{2}$ of 0.34 and a RMSE of \pm 65.8 Euro $/ \mathrm{m}^{3}$ while in the present study an overall $r^{2}$ of 0.66 and a RMSE of $\pm 38.6 \mathrm{Euro} / \mathrm{m}^{3}$ were achieved. Even when information on the type of the buyer (timber-export-corporations, timber exporting and high quality veneer producing corporations, saw mill industry, low quality veneer producers, high quality veneer corporations) was integrated in Stang's study as an independent, the $r^{2}$ increased to a value no greater than 0.53 . The RMSE remained with \pm 58.8 Euro $/ \mathrm{m}^{3}$ at a high level. Göttlein [11] achieved an $r^{2}$ between 0.35 and 0.43 for price predictions on "veneer-oak". The partial $r^{2}$ of the quality variables varied between 0.10 and 0.11 while quality variables in the present study obtained a partial $r^{2}$ of 0.16 (for the "Preference-quality-model"). As in the study of Göttlein [11] the present investigation revealed a great contribution of $\log$ size variables to the explanation of price dispersion. Especially the log length was important, explaining $35 \%$ of the dispersion alone. The logs' length might already reflect a part of the timber quality, since the higher the $\log$ quality, the longer it will be formed.

One may argue that the comparison of $r^{2}$ of the present models with others has no meaning because the models as presented in this study generally cannot explain a very high proportion of the price variation. Nevertheless, in order to evaluate the appropriateness of a model, one has to compare it with existing ones. Of course the logic behind the models and the variables included are more important than the $r^{2}$. Our models are consistent with economic theory and almost all the variables included have been used as quality measures in timber grading and classification schemes. The signs of all parameters are as expected. These requirements of model validity are frequently also given for other models. Therefore, the remnants are often a comparison of statistical measures of accuracy as the $r^{2}$ and the RMSE, which are commonly reported and can be compared.

Moreover, it is clear that different buyers would evaluate an equal quality differently because of their different needs. This fact is probably the most important source of the remaining dispersion, which could not explained by the models. However, science strives for results which can be generalised at least in part. Here it was not possible to include the subjective needs of every single buyer. Maybe this would have raised the $r^{2}$ almost to 1.0 .

The second hypothesis to test was:

$\mathrm{H} 2$ : "Among the quality variables the "red heartwood" looses on relevance."

"Red heartwood" still proved to be the most important quality variable of high quality beech timber. Therefore, also hypothesis $\mathrm{H} 2$ can be rejected. The over 30 year old valuation of Necesany [26] is apparently still valid. Manufacturing nice furniture or stairs from beech with "red heartwood" will call for greater costs also in future [30]. From this point of view advertising campaigns have not only to inspire consumers for a "red heartwood" timber preference as great as for "white" beech. In fact the consumer preference for the "red heartwood" timber must be increased to become even substantially greater than that for "white timber". In this context forestry should not forget that advertising campaigns will also effort substantial costs.

Eventually a third hypothesis was tested:

H3: "The "Price-preference-model" and the "Preferencequality-model" is to be the same for European and Asian buyers."

Analysing this hypothesis revealed clear differences between European and Asian buyers. This lead to rejecting hypothesis H3. While the Asian buyers were more interested in large logs, the European buyers differentiated their preferences more with regard to the timber quality. They would, for example, rather buy stems with "red heartwood" comprising less than $30 \%$ of the stem's diameter, while Asian buyers would accept a higher amount of "red heartwood".

Interestingly, the explanatory power of the separate models was significantly lower when compared to the original overall model. For the price explanation it seems important to analyse the whole preference structure of all buyers for the logs. Separating the buyer's preference into the groups European and Asian obviously reduced the accuracy of the price predictions. However, an interesting insight into the different requirements of European and Asian buyers was possible by carrying out the differentiation.

\subsection{Methodological approach}

Basically we can call the methodology applied "hedonic pricing" (e.g., [18, 19, 41]). "Hedonic pricing" analyses overall good prices and statistically explains prices with internal characteristics of the goods. Only the independent variable "quantity of log type" cannot be seen as an internal characteristic of the timber. However, the quantity offered of a specific log type was not very important for the timber price achieved. 
Table IX. Comparison of price reductions caused by "red heartwood".

\begin{tabular}{|c|c|c|c|c|}
\hline & \multirow[t]{2}{*}{$\begin{array}{l}\text { According to } \\
\text { present study }\end{array}$} & \multirow[t]{2}{*}{$\begin{array}{c}\text { According to Knoke } \\
\text { ([16], p. 25) }\end{array}$} & \multicolumn{2}{|c|}{$\begin{array}{l}\text { According to Naumann } \\
\text { Jülich ([25], p. 158) }\end{array}$} \\
\hline & & & Quality grade & $\begin{array}{l}\text { Compared with } \\
\text { quality grade A }\end{array}$ \\
\hline Class 2: $>0$ up to $30 \%$ & $-10 \%$ & $-22 \%$ & B & $-21 \%$ \\
\hline Class 3: $>30$ up to $50 \%$ & $-25 \%$ & $-40 \%$ & $\mathrm{C}$ & $-38 \%$ \\
\hline Class 4: > 50\% & $-36 \%$ & $-70 \%$ & $\mathrm{D}$ & $-68 \%$ \\
\hline
\end{tabular}

Merely in the case that a specific log type was very scarce was the timber price substantially increased. The small or even missing effect of the quantity offered on the timber price is in line with the economic theory when considering the special situation analysed. The effect of downwards sloping demand curves occurs only if the quantities offered are large enough. In our case the quantity offered of every specific log type was rather small. Given only small quantities, the Forest Service was not able to influence the market price. In such cases demand curves which are parallel to the $\mathrm{X}$-axis (quantity offered) are expected (see [42], p. 223).

Using regression analysis in order to derive prices depending on the timber log's internal characteristics, we applied a typical econometric approach. The structures of the regression curves were based on economic theory. This classical econometric methodology (marriage of theory and evidence) sometimes called for criticism. It is seen as “... largely old theory in the sense that it does not embody full stochastic dynamic optimisation with incomplete markets", as Pesaran and Smith ([27], p. 65) pointed out. But in this study it was not the object to integrate and quantify uncertainty. Rather, the interesting relationship between the timber quality variables was investigated. However, according to Pesaran and Smith ([27], p. 65) also the estimated relationships between variables observed would not be stable. In this study, at least the ranking of the importance of the timber quality variables was largely consistent with opinions published by other authors (e.g., Seeling [37]). However, the price reducing effect of the quality variable "red heartwood" is not consistent with other studies. This becomes obvious when the relative amount of price decrease is compared (Tab. IX).

While here prices decreased between 10 and $36 \%$ when "red heartwood" classes worsened a former investigation was based on price reductions between 22 and even 70\% ([16], p. 25). Also the price relation between beech timber quality grades (see [25]), which is substantially influenced by "red heartwood", reflects the relationship applied by Knoke [16]. As the data analysed in the latter study did not only comprise of timber prices derived from auctions but also on conventionally sold timber, it is likely that a special case was analysed in the present study. Auctions often increase the level of the achieved prices [32]. Moreover, the timber logs were subject to a pre-selection according to their quality. Consequently, the full dispersion of qualities was already reduced. Furthermore, the data analysed here were recorded during a period of a very great demand for beech timber from Asia. This fact may have increased the tolerance of the timber buyers regarding quality constraints. This would mean that the importance of the identified relevant timber quality variables has been rather underestimated by the present study. In view of quality variables showing relevance even under these conditions, it can be stated that they are surely of importance. However, it is likely that some significant variables were not identified, though important, which would have been relevant when looking at the whole population of beech log qualities.

Despite these concerns, the ranking of quality variables derived with the present study seems quite robust and beneficial for improving beech management. It could particularly be confirmed that the "red heartwood" of beech is still highly relevant. Studies focussing on how quality variables may be considered within the beech management, as carried out by Knoke [15-17] for the variable "red heartwood", are now essential in order to increase financial return of beech timber management.

Acknowledgements: The authors wish to thank Diplom-Forstwirt Johannes Wurm for useful comments, Mrs. Edith Lubitz for the language editing of the manuscript and an anonymous reviewer for valuable suggestions regarding a separate evaluation of the data for European and Asian buyers.

\section{REFERENCES}

[1] Alderman D., Wiedenbeck J., Peter P., Brinberg D., Key attributes associated with veneer quality timber that may be impacted by forest management practices, in: Proceedings of the 14th Central Hardwood Forest Conference, March 16-19; Wooster, OH. Gen. Tech. Rep. NE-316, Newtown Square, PA: U.S. Department of Agriculture, Forest Service, Northeastern Research Station, 2004, $140-147$.

[2] Ammer C., Dingel C., Untersuchungen über den Einfluß starker Weichlaubholzkonkurrenz auf das Wachstum und die Qualität junger Stieleichen, Forstw. Cbl. 116 (1997) 346-358.

[3] Athey S., Levin J., Information and Competition in US Forest Service Timber Auctions, J. Polit. Econ. 109 (2001) 375-417.

[4] Baßeler U., Heinrich J., Utecht B., Grundlagen und Probleme der Volkswirtschaft, 17. Auflage, Stuttgart: Schäffer-Poeschel, 2002.

[5] Bloomberg M., Bigsby H., Sedcole R., Regional variation in radiata pine sawlog prices in New Zealand, N.Z. J. For. 47 (2002) 25-27.

[6] Bouriaud O., Bréda N., Le Moguédec G., Nepveu G., Modelling variability of wood density in beech as affected by ring age, radial growth and climate, Trees 18 (2004) 264-276. 
[7] Brandl H., Ergänzende Untersuchungen zur Ertragslage der Baumarten Fichte, Kiefer, Buche und Eiche in Baden-Württemberg, Allgem. Forst- u. J.-Ztg. 160 (1989) 91-98.

[8] EN 1316-1, Hardwood round timber - Qualitative classification Part 1: Oak and beech, Published 1997/05/01.

[9] Ferrand J.C., Study of growth stresses. 2. Variations of growth stresses of beech, Ann. Sci. For. 39 (1981) 178-218.

[10] Freund R.J., Littell R.C., SAS System for Regression, SAS series in statistical applications, Cary: SAS Institute Inc, 1991.

[11] Göttlein A., Der Einfluss von Baumdimension, Standort und Holzqualität auf den Versteigerungserlös von Funiereichen, Forstwiss. Centralbl. 113 (1994) 354-366.

[12] Guilley E., Hervé J.C., Huber F., Nepveu G., Modelling variability of within-rings density components in Quercus petraea Liebl. with mixed-effects models and simulating the influence of contrasting silvicultures on wood density, Ann. For. Sci. 56 (1999) 449-348.

[13] Hansen J.K., Jørgensen B.B., Stoltze P., Variation of quality and predicted economic returns between European beech (Fagus sylvatica L.) provenances, Silvae Genetica 52 (2003) 185-197.

[14] Harris J.M., Spiral grain and wave phenomena in wood formation, Berlin, Heidelberg, Springer, 1989.

[15] Knoke T., Value of perfect information on red heartwood formation in beech (Fagus sylvatica L.), Silva Fenn. 36 (2002) 841-851.

[16] Knoke T., Eine Bewertung von Nutzungsstrategien in Buchenbeständen (Fagus sylvatica L.) vor dem Hintergrund des Risikos der Farbkernbildung - eine waldbaulich-forstökonomische Studie, Forstliche Forschungsberichte München Nr. 193, 2003.

[17] Knoke T., Predicting red heartwood formation in beech trees (Fagus sylvatica L.), Ecol. Model. 169 (2003) 295-312.

[18] Le Goffe P., Hedonic Pricing of Agriculture and Forestry Externalities, Environ. Resource Economics 15 (2000) 397-401.

[19] Lee J., Kwak S.-J., List J.A., Average Derivative Estimation of Hedonic Price Models, Environ. Resource Economics 16 (2000) 81-91.

[20] Mankiw N.G., Grundzüge der Volkswirtschaftslehre. 2, überarbeitete Auflage, Stuttgart: Schäffer-Poeschel, 2001.

[21] Mayer-Wegelin H., Mammen E., Spannungen und Spannungsrisse im Buchenstammholz, Allgem. Forst- u. J.-Ztg. 125 (1954) 287297.

[22] Metrick A., Zeckhauser R., Price versus quantity: market-clearing mechanisms. When consumers are uncertain about quality, J. Risk Uncertainty 17 (1999) 215-242.

[23] Mosandl R., El Kateb H., Ecker J., Untersuchungen zur Behandlung von jungen Eichenbeständen, Forstw. Cbl. 100 (1991) 258-370.

[24] Mühle D., Untersuchung zur Bedeutung von Rundholzfehlern an Buche und Kiefer für die holzverarbeitende Industrie, Diplomarbeit Fachhochschule Eberswalde, 2000, Not published.

[25] Naumann A., Jülich L., Berücksichtigung von Rot- und Spritzkern bei der Holznutzung, Allgem. Forstz./Der Wald 52 (1997) 157-159.

[26] Necesany V., Forstliche Aspekte bei der Entstehung des Falschkernes bei der Buche, Holz-Zentralblatt 95 (1969) 563-564.
[27] Pesaran M.H., Smith R., The role of theory in econometrics, J. Econom. 67 (1995) 61-79.

[28] Polge H., Influence of the thinning regime on growth stresses in beech, Ann. Sci. For. 38 (1981) 407-423.

[29] Quinn G.P., Keough M.J., Experimental design and data analysis for biologists, Cambridge, New York [u.a.]: Cambridge University Press, 2002

[30] Rathke K.-H., Zu: Rotkern bei Buche, Allg. Forstz./Der Wald 51 (1996) 1312.

[31] Reddy V.S., Bush R.J., Measuring Softwood Lumber Value: A Conjoint Analysis Approach, For. Sci. 44 (1998) 145-157.

[32] Renneke R., Determinanten des Jagdpachtpreises - Eine empirische Studie für Nordrhein-Westfalen, Dissertation am Wissenschaftszentrum Weihenstephan für Ernährung, Landnutzung und Umwelt, TU München, 2004.

[33] Richter J., In wie weit sind Kronenform und Schaftqualität der Rotbuche genetisch bedingt? Forst Holz 54 (1999) 460-462.

[34] Richter J., Buchenrotkern: Vermeiden oder Verwerten? Forst Holz 56 (2001) 662-664.

[35] Sachsse H., Kerntypen der Rotbuche, Forstarchiv 62 (1991) 238 242.

[36] Schulz H., Über die Zusammenhänge zwischen Baumgestalt und Güte des Schnittholzes bei der Buche, Schriftenreihe der Forstlichen Fakultät der Universität Göttingen und Mitteilungen der Niedersächsischen Forstlichen Versuchsanstalt, Band 29, 1961.

[37] Seeling U., Kerntypen im Holz - Konsequenzen für die Verwertung am Beispiel der Buche (Fagus sylvatica L.), Schweiz. Z. Forstwes. 149 (1998) 991-1004.

[38] Seifert T., Integration von Holzqualität und Holzsortierung in behandlungssensitive Waldwachstumsmodelle, Dissertation Technische Universität München, Fakultät Wissenschaftszentrum Weihenstephan für Ernährung, Landnutzung und Umwelt, 320 S, 2003 [http://tumb1.biblio.tu-muenchen.de/publ/diss/ ww/2003/seifert.html].

[39] Seifert T., Pretzsch H., Bücking M., Mittelwaldfichten aus dem Hochwald - Teil II: Jahrringbreiten, Abholzigkeit und Astigkeit langkroniger Fichten, Forst Holz 58 (2003) 473-477.

[40] Stang S., Zum Einfluss von Rundholzmerkmalen der Buche auf die Ergebnisse zweier Wertholzsubmissionen, Diploma-thesis, Studienfakultät für Forstwissenschaft und Ressourcenmanagement, TU München, 2003, unpublished.

[41] Steiner B.E., Australian Wines in the British Wine Market: A Hedonic Price Analysis, Agribusiness 20 (2004) 287-307.

[42] Thommen J.-P., Achleitner A.-K., Allgemeine Betriebswirtschaftslehre. 4, überarbeitete und erweiterte Auflage, Wiesbaden: Gabler, 2003

[43] Wilhelmsson L., Arlinger J., Spångberg K., Lundqvist O., Grahn T., Hedenberg Ö., Olsson L., Models for Predicting Wood Properties in Stems of Picea abies and Pinus sylvestris in Sweden, Scand. J. For. Res. 17 (2002) 330-350. 